\title{
Lithostratigraphy and Microbiostratigraphy of Gadvan and Darian Formations in South Semirom, East of Zagros Basin, South-Central Iran
}

\author{
Mohammad Kazem Hamedanian1, Seyed Hamid Vaziri² ${ }^{*}$, Mahnaz Amir Shakarami³, \\ Mehran Arian', Naser Arzani ${ }^{3}$
}

${ }^{1}$ Department of Geology, Science and Research Branch, Islamic Azad University, Tehran, Iran

${ }^{2}$ Department of Geology, North Tehran Branch, Islamic Azad University, Tehran, Iran

${ }^{3}$ Department of Geology, Payam Noor University, Isfahan, Iran

Email: ^h_vaziri@iau-tnb.ac.ir

How to cite this paper: Hamedanian, M.K., Vaziri, S.H., Shakarami, M.A., Arian, M. and Arzani, N. (2017) Lithostratigraphy and Microbiostratigraphy of Gadvan and Darian Formations in South Semirom, East of Zagros Basin, South-Central Iran. Open Journal of Geology, 7, 119-131. https://doi.org/10.4236/ojg.2017.72008

Received: November 15, 2016

Accepted: February 19, 2017

Published: February 22, 2017

Copyright ( $\odot 2017$ by authors and Scientific Research Publishing Inc. This work is licensed under the Creative Commons Attribution-NonCommercial International License (CC BY-NC 4.0). http://creativecommons.org/licenses/by-nc/4.0/ (c) (i) (8) Open Access

\begin{abstract}
This research focuses on the lithostratigraphy and microbiostratigraphy implications of the Gadvan and Darian Formations in a part of Zagros sedimentary basin. The Gadvan and Darian Formations in the study area with a thickness of 520 meters consist of gray to green marls and shales, dark-grey limestones and Orbitolina limestone with Late Barremian-Aptian age. According to the lithostratigraphic investigations, the Gadvan and Darian Formations in the study area are subdivided into eleven units. The upper boundary of the Darian Formation with the Kazhdomi Formation and the lower boundary of Gadvan Formation with the Fahliyan Formation are in the form of disconformity. Micropaleontological study of the Gadvan and Dariyan Formations has led to the recognition 20 families, 45 genera, 35 species of benthic foraminifera, 2 genera of pelagic foraminifera and 8 genera and species of the calcareous algae. In this research, three biozones have been recognized by distribution of the larger benthic foraminifera in the Gadvan and Dariyan Formations of the South Semirom, including: 1) Palorbitolina lenticularis-Choffatella decipiens Concurrent Range Zone (middle Late Barremian to early Early Aptian); 2) Praeorbitolina cormyi-Orbitolina (Mesorbitolina) lotzei Assemblage Zone (late Early Aptian); 3): Orbitolina (Mesorbitolina) texanae-Orbitolina (Mesorbitolina) parva Assemblage Zone (Middle to Late Aptian). Based on the identified foraminifera, the age of the Gadvan and Darian Formations in the study area is assigned to Late Barremian to Aptian.
\end{abstract}

\section{Keywords}

Lower Cretaceous, Foraminifera, Gadvan, Darian, Biozone, Zagros, Semirom 


\section{Introduction}

The Gadvan and Darian Formations are thick carbonate strata as a part of Khami Group which is deposited in Zagros Zone, in south margin of Neotethys. According to James and Wynd [1] in Jurassic to Early Cretaceous period, a sedimentary cycle which is composed of the Surmeh, Hith, Fahliyan, Gadvan and Dariyan Formations in Zagros are called as Khami Group. The type sections of Gadvan and Darian Formations are located $50 \mathrm{~km}$ from eastern end of the Shiraz Mountain. The Gadvan and Darian Formations in the studied section have a thickness of 520 meters in the south of Semirom in the southern slopes of Agh Dagh Mountain in high Zagros Zone. The main objectives of this paper are to describe and interpret the lithostratigraphy and microbiostratigraphy of the Gadvan and Darian Formations in the study area in order to understand the geological evolution of the area during that time interval. The lithological aspect of the Gadvan and Darian Formations is generally composed of thin- to medium-bedded marly limestone, fossiliferous limestone (Gulf limestone), nodular limestones and gray to brown, thick-bedded to massive Orbitolina sandy limestone according to James and Wynd [1], Kalantari [2]. The Darian Formation is overlaid conformably on the marls of the Gadvan Formation as a gradational lithostratigraphic limit. Since the biostratigraphic limits of the Aptian successions change in some parts of the Zagros Basin, Aptian biostratigraphy can be used as a tool for the interpretation of faunal assemblage characteristics along the Zagros area.

\section{Materials and Methods}

Thin sections of collected samples from the Gadvan and Darian Formations in the study area were studied under a binocular microscope and as a result, some microfauna and 3 biozones were detected. Recognized biozones are in consistency with biozones named by Schroeder et al. [3], Schroeder and Newman [4], Arnaud-Vanneau [5], Granier et al. [6], Arnaud et al. [7], Conrad et al. [8], Simmons [9], Simmons et al. [10], Bachmann and Hirsch [11], Harris et al. [12], Husinec et al. [13], Husinec [14], Wynd [15], Velic and Tisljar [16], Velic and Tisljar [17], Gollesstaneh [18], and for the study of microfauna the concepts of Khosrotehrani [19] [20], Sampo [21], Loeblich and Tappan [22], Boudagher-Fadel [23], Kalantary [24], Mehrnush and Partoazar [25]. Through studying final reports and thin sections; identification of microfossils and photography, preparation of microfossil's plates and their distribution in stratigraphy column and displaying detected zones have been done.

\section{Study Area}

The study area is located in the south of Semirom (geological map of Semirom on scale 1/100,000) and the south slopes of Agh Dagh Mountain, in the Zagros folded. In the study section with co-ordinates: $31^{\circ} 05^{\prime} 08^{\prime \prime} \mathrm{N}$; $51^{\circ} 55^{\prime} 14^{\prime \prime} \mathrm{E}$ (Figure 1 ), the Gadvan Formation $(150 \mathrm{~m})$ consists of thin- to medium-bedded marly limestone, marl, fossiliferous limestone and nodular limestone, and the Dariyan Formation $(370 \mathrm{~m})$ consists of medium- to thick-bedded Orbitolina limestones (Figure 2). 

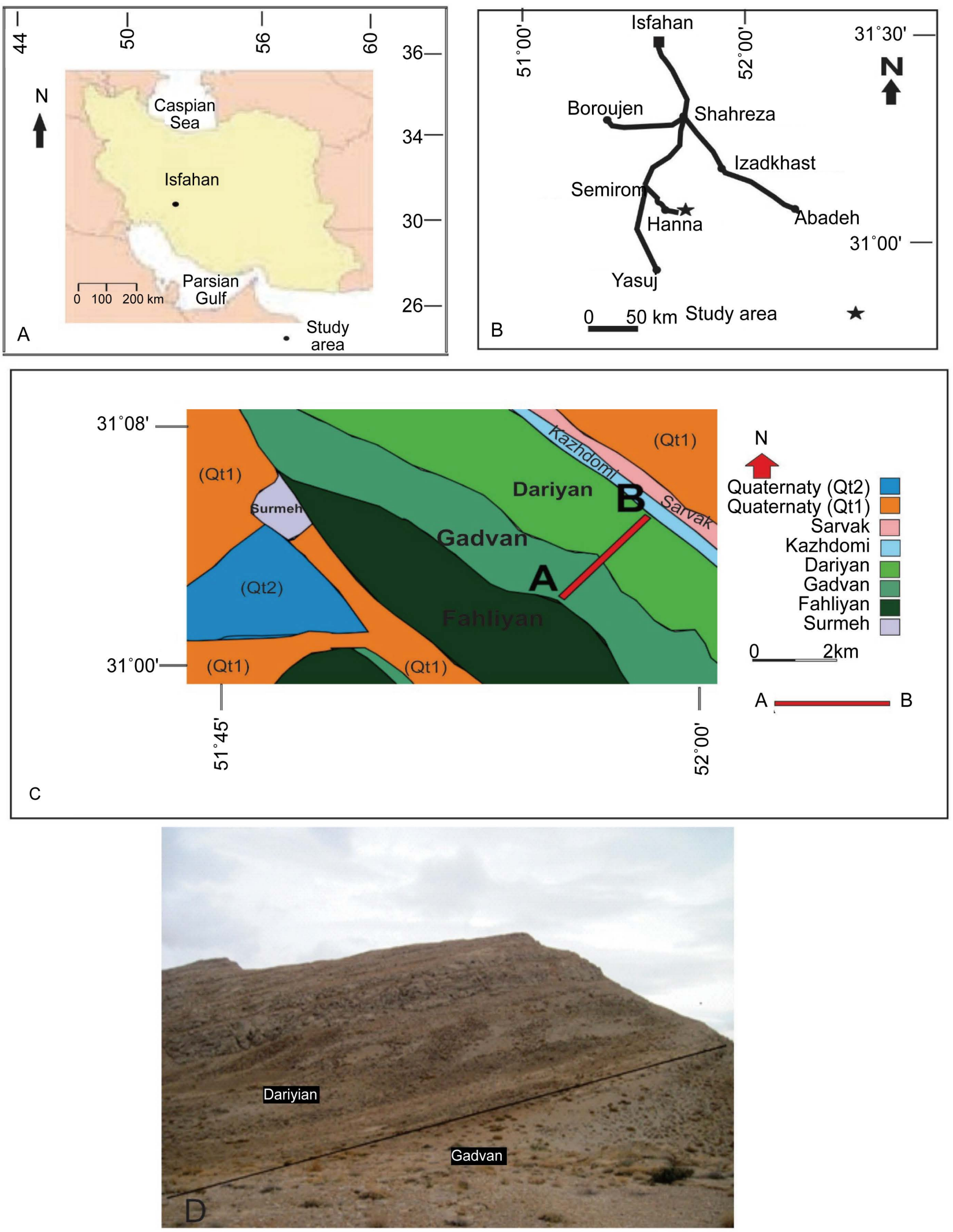

Figure 1. (A) Showing the study area in Iran, (B) Location and access roads to the study area in south of Semirom, Zagros Basin, (C) Location of the studied section in geological map of Semirom (scale 1/100,000) [26], (D) View of the Agh Dagh Mountain in southern Semirom, photo is looking to north. 

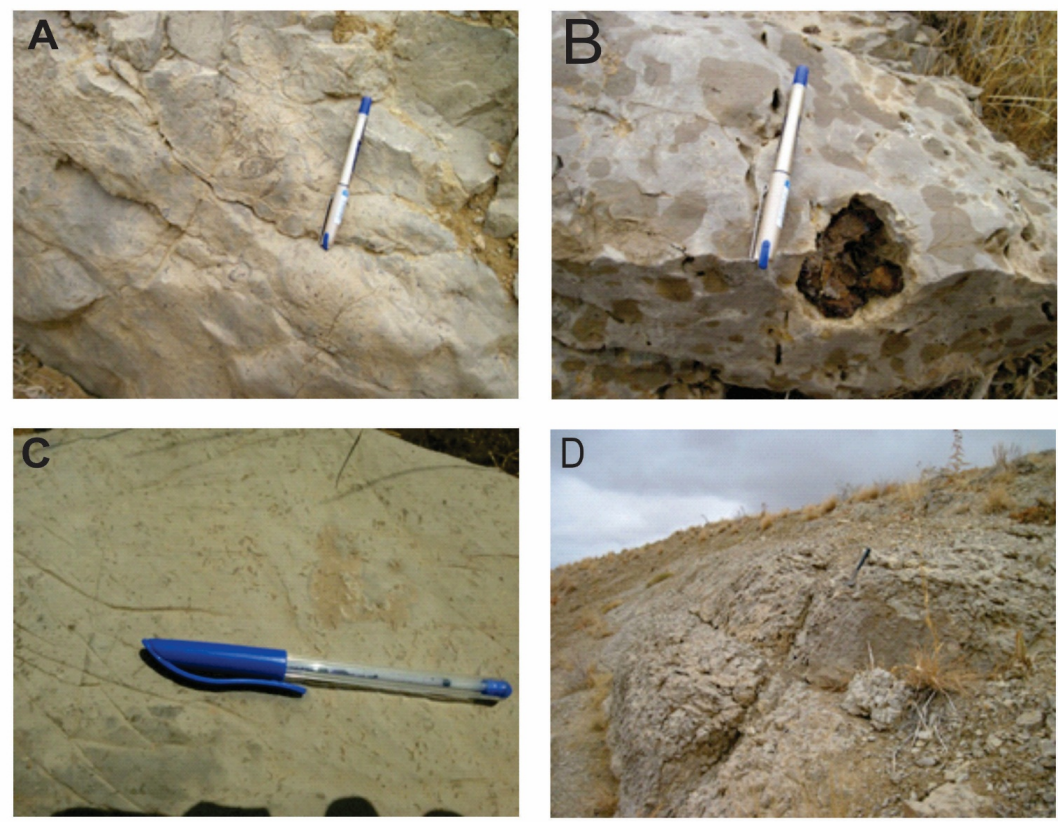

Figure 2. (A) Fossiliferous limestone, (B) Nodular limestone, (C) Orbitolina limestone, and (D) Thick-bedded limestone of Gadvan Formation.

\subsection{Lithostratigraphy}

A) Gadvan Formation: This formation with a thickness of 150 meters consists of thin- to medium-bedded marly limestone, fossiliferous limestone (Gulf limestone) and nodular limestone.

B) Darian Formation: This formation with a thickness of 370 meters consists of fossiliferous limestone and, middle- and thick-bedded Orbitolina limestone (Figure 2).

\subsection{Research Method}

The best stratigraphic section of Gadvan and Darian Formations in the study area selected and, systematic sampling was done on the basis of lithological and facies changes and in total 130 samples were collected. The study carried out for achieving the desired goals and objectives included two stages: field studies and Laboratory studies.

1) Field studies: First an investigation of the geological evidence was done together with a choice of the best section of the Gadvan and Darian Formations in the study area and then 130 samples were taken of the total thickness of 520 meters basis on the facies and lithological changes.

2) Laboratory studies: Microscopic thin sections were prepared and studied with a polarized microscope. Also Pictures were taken of typical samples.

Gadvan Formation: Limestones of the Gadvan Formation with a thickness of 150 meters lies on Fahliyan Formation as a disconformity. These comprise the following:

1) 35 meters of light-gray, medium-bedded Orbitolina marly limestones and 
trace of bivalves.

2) 15 meters of alluvial deposits were observed which had covered Gadvan Formation.

3) 35 meters of light-gray, medium marly limestones with a trace of bivalve and microfossil.

4) 35 meters of light-gray, medium-bedded to thick-bedded limestones (Bay or Gulf limestones); on the surface have traces of irregular fractures and severe local fragmentations were observed. The thickness of the layers is not fixed and, at times, amounts to 100 centimeters (Figure 1). With regard to fossilization, this layer is a bit poor compared to the lower layers.

5) 30 meters of light-gray, medium-bedded marly limestones which have iron silica nodules and pieces of bivalves and gastropods (Figure 3 ).

\subsection{Darian Formation}

This formation lies on Gadvan Formation continuously. The distinguishing features are the salient increase of benthic microfossils especially Orbitolinidae family and lack of marly sediments. Layers of Darian Formation generally bear

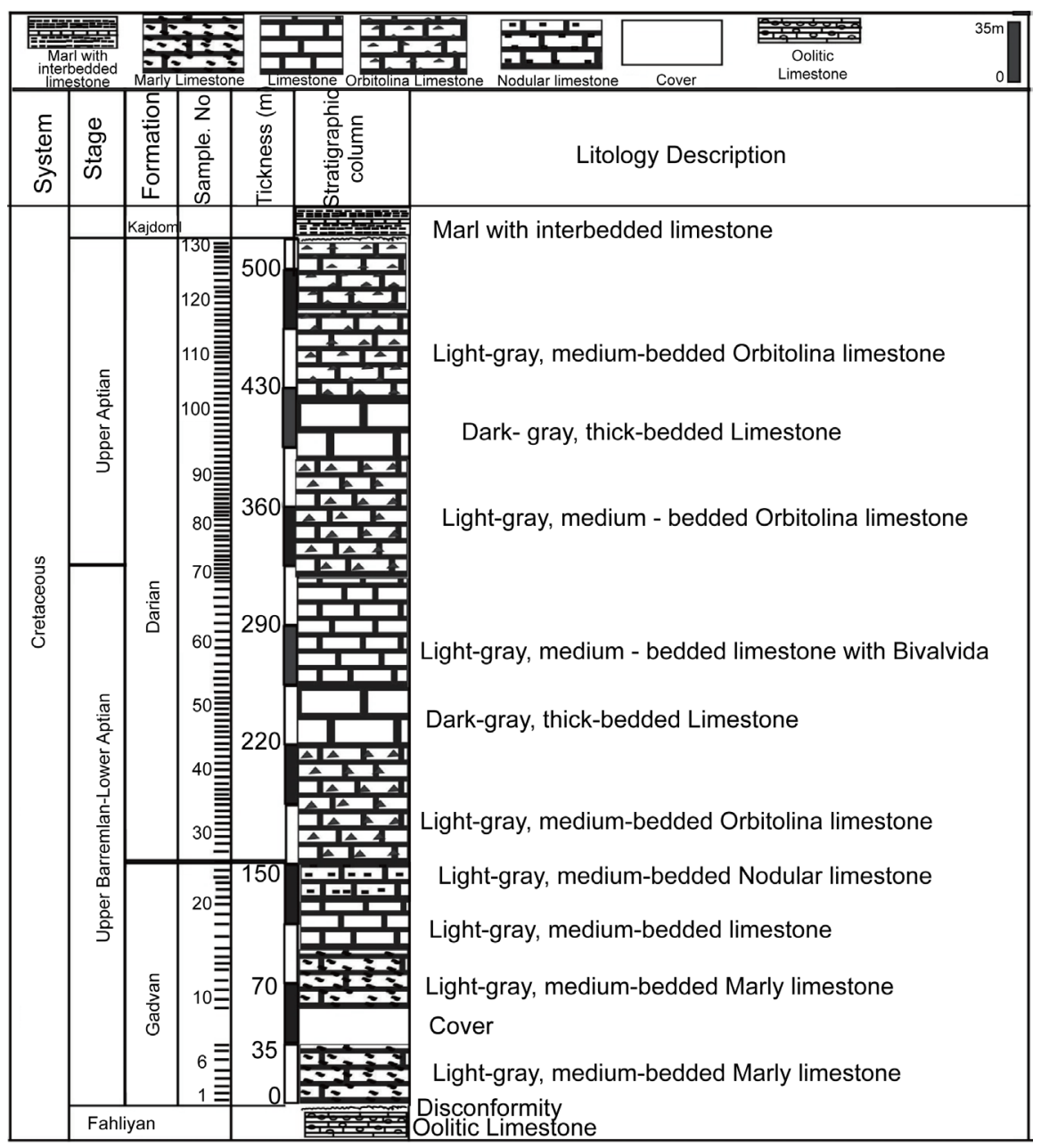

Figure 3. Lithological characteristics of the Gadvan and Darian Formations at the Agh Dagh Mountain in South of Semirom. 
no considerable variety in color and light-gray, but regarding thickness, they are varied, and that is, they are thin to thick-bedded. Lithologically, this formation is divided into the following units:

1) 70 meters of light-gray, medium-bedded Orbitolina limestones.

2) 30 meters of light-gray, thick-bedded limestones. They have gaps and crack which are later filled with light color cement and are rather poor regarding fossilization.

3) 75 meters of light-gray, medium-bedded limestones. They include large and stretched bivalve's pieces and are poor in terms of microfossils.

4) 70 meters of light-gray, medium-bedded Orbitolina limestones.

5) 30 meters of light-gray, thick-bedded limestones which are rather poor in terms of fossilization.

6) 95 meters of light-gray, medium-bedded Orbitolina limestones (Figure 3).

\subsection{Microbiostratigraphy of the Gadvan and Darian Formations}

According to studied microfauna, Gadvan and Darian Formations are very rich in terms of fossil contents which can be utilized in determining the age (Figure 4) and identifying the sedimentary environment. This is 130 samples were taken regularly and systematically in order to identify and describe foraminifera and non-foraminifera time development, biozonation, and age determination of Gadvan and Darian Formations in the study area. These were studied and photographed after preparation of thin section and segments and labeling. For the purpose of the study, the following sources and articles have been used; Khosro-tehrani [20], Sampo [21], Loeblich and Tappan [22], Boudagher-Fadel [23], Kalantary [24], Mehrnush and Partoazar [25]. Micropaleontological study of the Gadvan and Dariyan Formations has led to the recognition 20 families, 45 genera, 35 species of benthic foraminifera, 2 genera of pelagic foraminifera and 8 genera and species of the calcareous algae include Trocholina elongata, Dictyoconus arabicus, Textularia sp., Lenticulina sp., Pseudocyclammina littus, Salpingoporell adinarica, Orbitolina sp., Pseudochrysalidina sp., Pseudocyclammina sp., Haplophragmoides sp., Cuneolina pavonia, Pseudochrysalidina arabica, Pseudochrysalidina infracretace, Trocholina sagitten, Montsecella sp., Charentia sp., Pseudolitunella recheli, Debarina hahounerensis, Nezzazatinella picardi, Archalveolina sp., Hemicyclammina praesigali, Charentia cuvillieri, Palorbitolina sp., Balkhania balkhanica, Palorbitolina ultima, Pfendrina globosa, Lithocodium aggregatum, Montiella elitzae, Permocalcalus sp., Montsecella sp., Choffatella sp., Choffatella decipiens, Nautiloculina oolithica, Pseudocyclammina hedbergi, Vercorsella arenata, Iraqia simplex, Orbitolina (Mesorbitolina) texana, Orbitolina (Mesorbitolina) parva, Orbitolina kurdica, Marssonella trochus, Rumanoloculina pseudominima, Cylindroporella sp., Actinoporell sp., Orbitolina (Mesorbitolina) lotzei, Palorbitolina lenticularis, Quinqueloculina sp., Praeorbitolina cormeyi, Everticyclammina hedbergi, Globigerinelloids sp., Hensonella sp., Hedbergella sp.

The biozonation of study sequence was done based on the frequency of larger 
foraminifers, especially Orbitolina with reference to their appearance and expiration in Late Barremian-Aptian related to shallow areas of the platform to the deep areas of the lagoon Pittet et al. [27].

Biozone I): Palorbitolina lenticularis-Choffatella decipiens Concurrent Range Zone (middle Late Barremian to early Early Aptian).

This biozone in this section stretches from the beginning up to sample No. 31 and is 180 meters thick (Figure 4). Its microfauna includes Trocholina elongata,

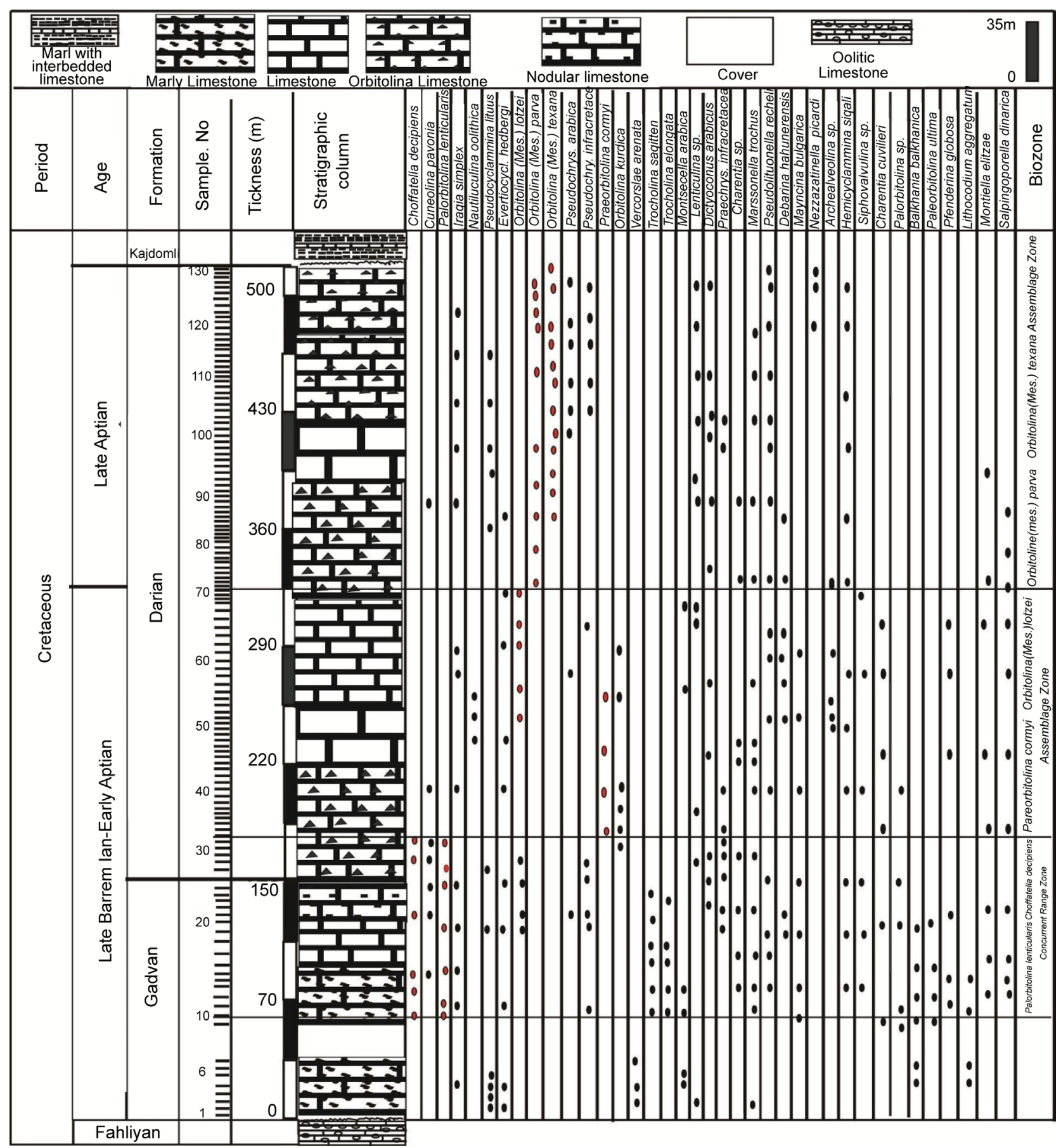

Figure 4. Microfossil distribution and biozonation of the Gadvan and Darian Formations at Agh Dagh Mountain in South of Semirom. 
Dictyoconus arabicus (Plat 1(B)), Textularia sp., Lenticulina sp., Pseudocyc lamminalittus (Plat 1(C)), Salpingoporella dinarica (Plat 1(J)), Orbitolina sp., Pseudochrysalidina sp., Pseudocyclammina sp., Haplophragmoides sp., Cuneolina pavonia (Plat 1(F)), Pseudochrysalidina arabica, Pseudochrysalidina infracretace, Trocholina sagitten, Montsecella Arabica (Plat 2(F)), Charentia sp. (Plat 1(L)), Pseudolitunella recheli (Plat 2(B)), Debarina hahounerensis, Nezzazatinella picardi, Archalveolina sp., Hemicyclammina sigali, Charentia cuvillieri,
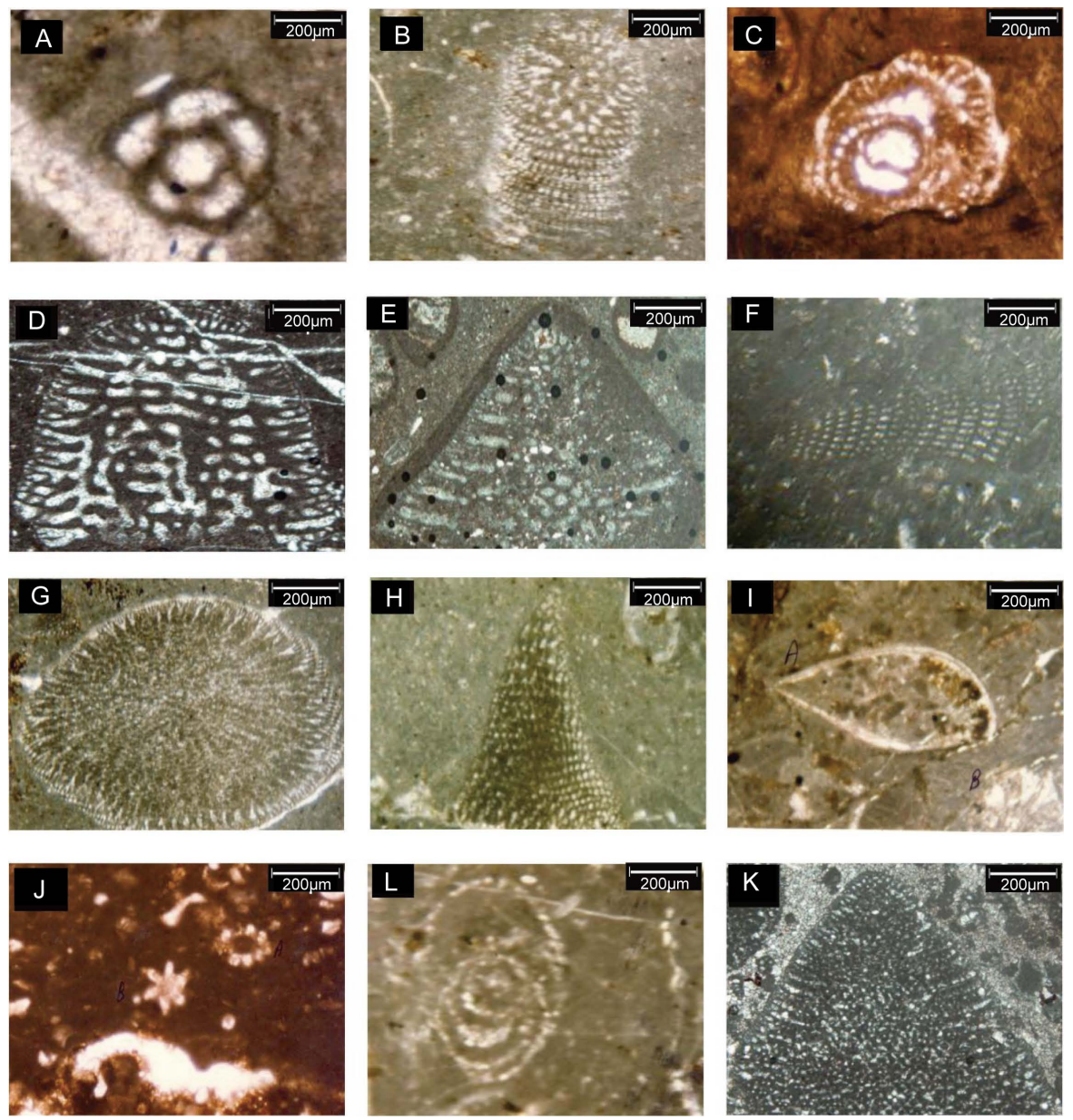

Plat 1. (A) Charentia sp., Neumann, 1965, longitude-oblique section, Sample no., S92, S115, Age: Middle to Late Aptian; (B) Dictyoconus arabicus, Guillaume, 1956, longitude section, Sample no., Transverse oblique section, no. S68, Age: Early to Late Aptian; (C) Pseudocyclammina lituus Maync, 1953, longitude-oblique section, Sample no., S5, S83, Age: Early to Middle Aptian; (D) Dictyoconus pachymarginalis, Schroeder, 1960, longitude section, Sample no., Transverse oblique section, no. S68, Age: Early to Late Aptian; (E) Praeorbitolina cormyi. Schroeder, 1965, Longitude section, Sample no., S40, S97, Age: Early Aptian; (F) Cuneolina pavonia, Dorbigny, 1949, longitude section, Sample no., S3, S7, Age: Aptian; (G) Orbitolina sp., 1849, Transverse oblique section, Sample no no. S15, Age: Early to Late Aptian; (H) Iraqia simplex Henson, 1948, Longitude section, Sample no., S40, S97, Age: Middle to Late Aptian; (I) Ostercoda; (J) Salpingoporella dinarica Radoicic, 1959, longitude-oblique section, Sample no., S14, S70, Age: Early to Middle Aptian; (L) Choffatella littus Schlumberger, 1905, longitude-oblique section, Sample no., S14, S70, Age: Early to Middle Aptian; (K) Mesorbitolina sp., 1849, longitude-oblique section, Sample no., S83, S106, Age: Middle to Late Aptian. 
Palorbitolina sp., Balkhania balkhanica (Plat 2(E)), Palorbitolina ultima, Pfendrina globosa, Lithocodium aggregatum, Montiella elitzae, Permocalcalus sp., Montsecella sp., Choffatella sp., Choffatella decipiens, Nautiloculina oolithica, Pseudocyclammina hedbergi, Vercorsella arenata (Plat 2(M)), Iraqia simplex (Plat 1(H)), Orbitolina kurdica, Marssonella trochus, Rumanoloculina pseudominima,
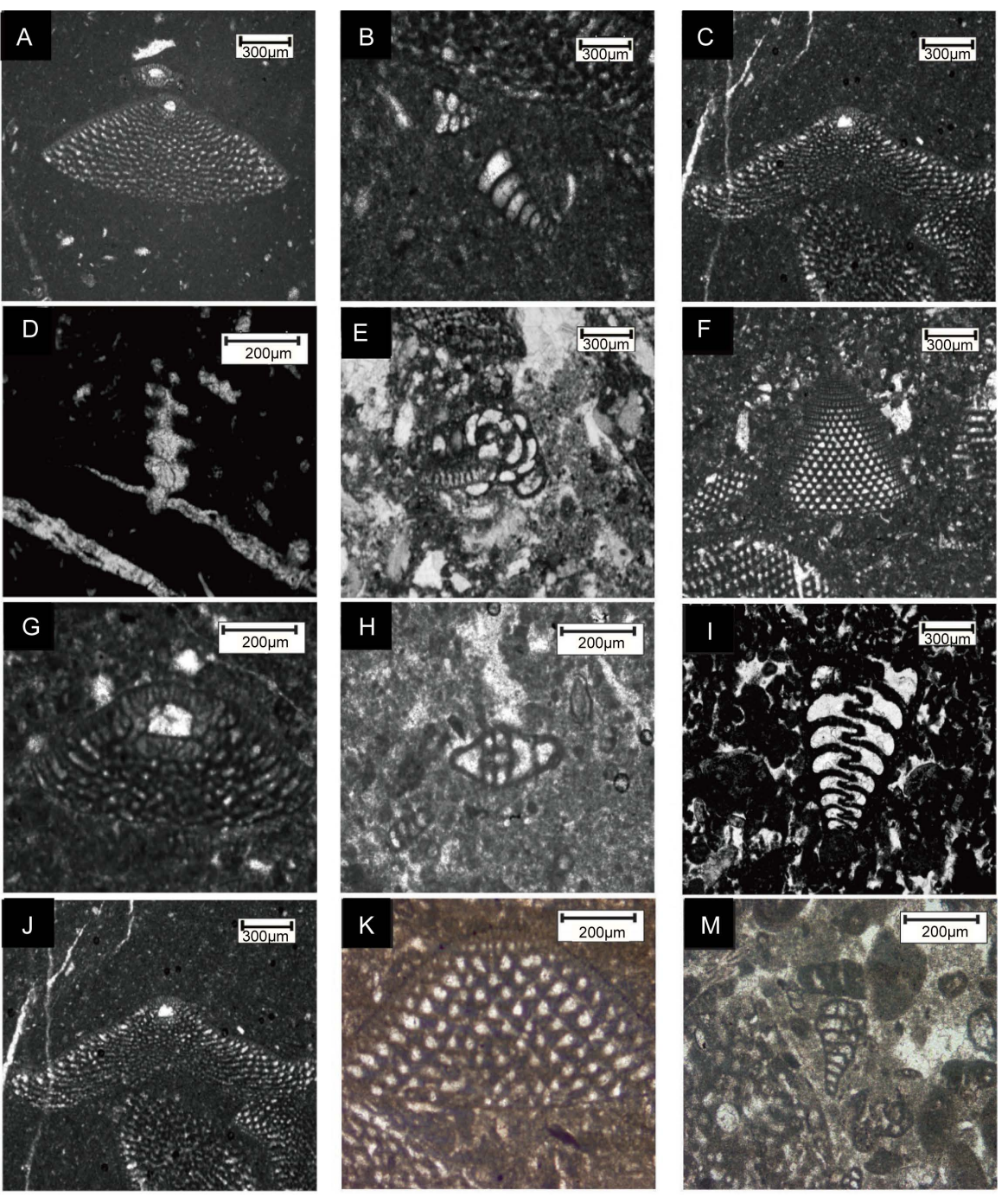

Plat 2. (A) Palorbitolina lenticularis Blumenbach, 1805, longitude-oblique section, Sample no., S14, S26, Age: Early Aptian; (B) Pseudolituonella recheli, Marie, 1955, Longitude section, Sample no., S40, S97, Age: Late Aptian; (C) Palorbitolina lenticularis Blumenbach, 1805, longitude-oblique section, Sample no., S14, S26, Age: Early Aptian; (D) Trocholina campanella, Arnaud-Vanneau 1988, longitude-oblique section, Sample no., S14, S26, Age: Early Aptian; (E) Balkhania balkhanica Mamontova, 1966, longitude section, Sample no., S5, S20, Age: Early Aptian; (F) Montseciella arabica Henson, 1948, Transverse oblique section, Sample no., S68, Age: Early to Late Aptian; (G) Mesorbitolina parva Douglas, 1960 longitude-oblique section, Sample no., S86, S126, Age: Middal to Late Aptian; (H) Nummuloculina sp., Steinmann, 1881, longitude section, Sample no., S5, S20, Age: Early Aptian; (I) Praechrysalidina infracretacea Luperto sinni, 1979, longitude section, Sample no., S22, S32, Age: Middle Aptian; (J), (K) Palorbitolina lenticularis Blumenbach, 1805, longitude-oblique section, Sample no., S14, S26, Age: Early Aptian; (M) Vercorsella arenata Arnaud-Vanneau, 1980, longitude section, Sample no., S2, S6, Age: Early Aptian. 
Cylindroporella sp., Actinoporell sp., Praechrysalidina infracretacea (Plat 2(I)), Palorbitolina lenticularis (Plat 2(A), Plat 2(C), Plat 2(J), Plat 2(K)), Quinqueloculina sp., Everticyclammina hedbergi, Globigerinelloids sp., Hensonella sp., Hedbergella sp., Dictyoconus pachymarginalis (Plat 1(D)), Gaudriyan sp., Trocholina campanella (Plat 2(D)).

This biozone has been reported by Schroeder et al. [3], Schroeder and Newman [4], Arnaud-Vanneau [5], Granier et al. [6], Arnaud et al. [7], Conrad et al. [8], Simmons [9], Simmons et al. [10], Bachmann and Hirsch [11], Harris et al. [12], Husinec et al. [13], Husinec [14], Wynd [15], Velic and Tisljar [16], Velic and Tisljar [17], Gollesstaneh [18]. The biozone has been reported from Oman, Iraq, Yemen, Bahrain, Qatar, Venezuela and various regions of Iran.

Biozone II): Praeorbitolina cormyi-Orbitolina (Mesorbitolina) lotzei Assemblage Zone (late Early Aptian).

This biozone in the studied section develops from sample 32 to 69 , and is 145 meters thick (Figure 4). Its microfauna includes Pseudochrysalidina arabica, Pseudochrysalidina infracretace, Iraqia simplex, Montiella elitzae, Hemicyclammina sigali, Dictyoconus arabicus, Textularia sp., Lenticulina sp., Archoalveolina sp., Quinqueloculina sp., Nezzazatinella picardi, Charentia cuvilieri, Charentia sp., Nezzazatinella picardi, Cuneolina pavonia, Everticyclammina hedbergi, Pseudolitunella recheli, Pfendrina globosa, Palorbitolina sp., Mayncina bulgarica, Siphoralulina sp., Orbitolina kurdica, Charentia cuvilieri, Montsecella Arabica, Pseudocyclammina hedbergi, Cylindroporella sp.

The fossiles which varnished in this Biozone are: Orbitolina (Mesorbitolina) lozei, Palorbitolina sp., Orbitolina kurdica, Palorbitolina lenticularis, Siphoralulina sp., Mayncina bulgarica, Nautiloculina oolithica, Praeorbitolina cormyi (Plat 1(E)), Orbitolina kurdica, Pfendrina globosa, Montsecella Arabica, Choffatella littus (Plat $1(\mathrm{~L})$ ).

This biozone has been reported by Schroeder et al. [3], Arnaud-Vanneau [5], Simmons et al. [10], Schroeder [28]. This biozone has been reported from Oman, Iraq, Yemen, Bahrain, Qatar, Southeast Ethiopia, and various locations of Iran.

Biozone III): Orbitolina (Mesorbitolina) texanae-Orbitolina (Mesorbitolina) parva Assemblage Zone (Middle to Late Aptian).

This biozone in the studied section stretches from sample No. 70 to 130, and is 195 meters thick (Figure 4). Its microfauna includes Dictyoconus arabicus, Textularia sp., Lenticulina sp., Pseudocyclammina littus, Orbitolina sp., Pseudochrysalidina sp., Pseudocyclammina sp., Pseudochrysalidina arabica, Pseudochrysalidina infracretace, Pseudolitunella recheli, Nezzazatinella picardi, Hemicyclammina sigali, Lithocodium aggregatum, Montiella elitzae, Permocalcalus sp., Montsecella sp., Pseudocyclammina hedbergi, Orbitolina (Mesorbitolina) texanae, Orbitolina (Mesorbitolina) parva (Plat 2(G)), Marssonella trochus, Rumanoloculina pseudominima, Cylindroporella sp., Actinoporell sp., Quinqueloculina sp., Iraqia simplex, Hemicyclammina sigali, Cuneolina pavonia, Charentia sp., Trocholina sagitten, Debarina hahounerensis, Salpingoporella dinaris, Archalveolina sp., Everticyclammina hedbergi, Cylindroporella sp., Nummuloculina 
sp. (Plat 2(H)).

The fossils which appeared in this biozone are: Nezzazatinella picardi Orbitolina (Mesorbitolina) texanae.

The fossiles which varnished in this biozone are: Pseudocyclammina littus, Montsecella sp., Iraqia simplex, Hemicyclammina sigali, Orbitolina (Mesorbitolina) texanae indicates the boundary between Middle-Late Aptian and Late Aptian in the Middle East and the Mediterranean region.

This biozone has been reported Arnaud-Vanneau [5], Rosenfeld et al. [29], Rosenfeld et al. [30], Matsukawa and Tomishita [31], Afghah et al. [32], Moosavizadeh et al. [33].

\section{Conclusion}

A rich foraminiferal, especially Orbitolina association has been determined in Late Barremian-Aptian limestones at the Agh Dagh Mountain in South of Semirom. According to the lithostratigraphic investigations, the Gadvan and Darian formations in the study area are subdivided into eleven units. Micropaleontological study of the Gadvan and Dariyan formations has led to the recognition of 20 families, 45 genera, 35 species of benthic foraminifera, 2 genera of pelagic foraminifera and 8 genera and species of the calcareous algae. In this research, three biozones have been recognized by distribution of the larger benthic foraminifera in the Gadvan and Dariyan formations of the South Semirom. The age of the Gadvan and Darian formations is Late Barremian-Aptian. These formations are represented by marly limestone and marl, and medium- to thickbedded limestone containing Orbitolina in the Zagros Basin. The Darian Formation overlies the Gadvan Formation and is covered by the Kazhdomi Formation. Orbitolinids in association with calcareous algae and echinoderms in slightly argillaceous limestones are interpreted to have been deposited in relatively high tropic conditions (mesotrophic).

\section{References}

[1] James, G.A. and Wynd, J.G. (1965) Stratigraphic Nomenclature of Iranian Oil Consortium Agreement Area. AAPG, 49, 2182-2245.

[2] Kalantary, A. (1979) Microbiostratigraphy of the Sarvestan Area, Southeastern Iran, N.I.O.C. Geological Laboratories, Pub No. 5, 129 p.

[3] Schroeder, R., Buchem, F., Cherchi, A., Baghbani, D., Vincent, B., Immenhauser, A. and Granier, B. (2010) Revised Orbitolinid Biostratigraphic Zonation for the Barremian-Aptian of the Eastern Arabian Plate and Implications for Regional Stratigraphic Correlations. Geo Arabia Special Publication 4, Gulf Petro Link, Bahrain, 1, 4996.

[4] Schroeder, R. and Neumann, M. (1985) Les grands Foraminife'res du Cre'tace' moyen de la re'gion Me'diterrane'enne. Geobios, Me'moire Spe'cial, 7, 1e160.

[5] Arnaud, H., Arnaud-Vanneau, A., Blanc-Ale'tru, M.-C., Adatte, T., Argot, M., Delanoy, G., Thieuloy, J.-P., Vermeulen, J., Virgone, A., Virlouvet, B. and Wermeille, S. (1998) Re'partition stratigraphique des orbitolinide's de la plate-forme urgonienne subalpine e t jurassienne (SE de la France). Géologie Alpine, 74, 3-89. 
[6] Arnaud-Vanneau, A. (Coordinator, Late Cretaceous) (1998) Chart 5 Larger Benthicforaminifera. In: Hardenbol, J., Jacquin, T., Farley, M.B., de Graciansky, P.-C. and Vail, P., Eds., Cretaceous Biochronostratigraphy, SEPM Special Publication, 60.

[7] Granier, B., Busnardo, R. and Pittet, B. (2011) New Data on the Hawar, Shu'aiba, $\mathrm{Bab}$, and Sabsab Regional Stages of the Lower Cretaceous in the United Arab Emirates and in Oman. In: Grosheny, D. and Granier, B., Eds., Platform to Basin Correlations in Cretaceous Times, Vol. 79-81, Boletín Del Instituto de Fisiografía y Geología, 11-13.

[8] Conrad, M.A., Schroeder, R., Clavel, B., Charollais, J., Busnardo, R., Cherchi, A. and Decrouez, D. (2004) Dating the Lower Cretaceous in the Organyà Section (Catalan Pyrenees, NE Spain): A Reinterpretation. Cretaceous Research, 25, 35-41.

https://doi.org/10.1016/j.cretres.2003.10.004

[9] Simmons, M.D. (1994) Micropalaeontological Biozonation of the Kahmah Group (Early Cretaceous), Central Oman Mountains. In: Simmons, M.D., Ed., Micropalaeontology and Hydrocarbon Exploration in the Middle East, British Micropalaeontological Society Publication Series, Chapmanand Hall, London, 177-219.

[10] Simmons, M.D., Whittaker, J.E. and Jones, R.W. (2000) Orbitolinids from Cretaceous Sediments of the Middle East-A Revision of the F.R.S. Henson and Associates Collection. In: Hart, M.B., Kaminski, M.A. and Smart, C.W., Eds., Proceedings of the 5 th International Workshop on Agglutinated, Foraminifera, Grzybowski Foundation Special Publication, 7, 411-437.

[11] Bachmann, M. and Hirsch, F. (2006) Lower Cretaceous Carbonate Platform of the Eastern Levant (Galilee and Golan Heights): Stratigraphy and Second-Order Sea Level Change. Cretaceous Research, 27, 487-512. https://doi.org/10.1016/j.cretres.2005.09.003

[12] Harris, P.M., Frost, S.H., Seiglie, G.A. and Schenidermann, N. (1984) Regional Unconformities and Depositional Cycles, Cretaceous of the Arabian Peninsula. In: Schlee, J.S., Ed., Interregional Unconformities and Hydrocarbon Accumulation, AAPG Memoir 36, 67-80.

[13] Husinec, A., Velic, I., Fucek, L., Vlalovic, I., Maticec, D., Ostric, N. and Korbar, T. (2000) Mid Cretaceous Orbitolinid (Foraminiferida) Record from Island of Cres and Losinj (Croatia) and Its Regional Stratigraphic Correlation. Cretaceous Research, 21, 155-171. https://doi.org/10.1006/cres.2000.0203

[14] Husinec, A. and Sokac, B. (2006) Early Cretaceous Benthic Associations (Foraminifera and Calcareous Algae) of a Shallow Tropical-Water Platform Environment (M1jet Island, Southern Croatia). Creataceous Research, 20, 1-24.

[15] Wynd, A.G. (1965) Biofacies of the Iranian Oil Consertium Agreement Area (IOOC) Report No. 1082 Baghin Fault System (Central Iran). Journal of Applied Environmental and Biological Sciences, 1, 382-396.

[16] Velic, I. and Tisljar, J. (1978) Biostratigraphic and Sedimentologic Characteristics of the Lower Cretaceous Deposits of the Veli Brijun Island and Comparison with the Corresponding Deposits in SW Istria (Western Croatia, Yugoslavia). Geološki Vjesnik, 40, 149-168.

[17] Velic, I. and Tisljar, J. (1978) Biostratigraphic Analysis of the Jurassic and Lower Cretaceous in the Wider Region of Ogulin, Central Croatia. Geološki Vjesnik, 30, 309-337.

[18] Golestaneh, A. (1965) Micropaleontological Study of Khami Group and JurassicCretaceous in Fars Province (Southern Iran). Bulletin de BRGM, No. 3, 165-197.

[19] Khosro-Tehrani, K. (1992) Micropaleontological Functional. Tehran University Press, Tehran, $353 \mathrm{p}$. 
[20] Khosro-Tehrani, K. (1992) Geology of Iran: Published in Kelidar. Payame Noor University, Payame.

[21] Sampo, M. (1969) Microfacies and Microfossile of the Zagros Area, SW Iran (from Permian to Miocene). International Sedimentary Petrographical Series, 12, 1-102.

[22] Loeblich, A.R. and Tappan, H. (1988) Foraminiferal Genera and Their Classification. Springer, Berlin, 970 p. https://doi.org/10.1007/978-1-4899-5760-3

[23] Boudagher-Fadel, M.K. (2008) Evolution and Geological Significance of Larger Benthic-Foraminifera, Evelopments in Palaeontology and Stratigraphy. Vol. 21. Elsevier, Amsterdam, 544.

[24] Kalantary, A. (1969) Microbiostratigraphy of the Cretaceous Lower Eocene Sucession Khoramabad-Kermanshah Area (W Iran). The Iranian Petroleum Institute, Bulten No. 48, 1-24.

[25] Mehrnush, W. and Partoazar, H. (1977) Selected Microfauna of Iran. Geological Survey of Iran, Report No. 33, 131159.

[26] Sadaght, M.A. and Shaverdi, I. (1999) Semirom Geological Map, Geological Survey Mineral Exploration.

[27] Pittet, B., van Buchem, F.S.P., Hillgartner, H., Razin, P., Grotsch, J. and Droste, H. (2002) Ecological Succession, Palaeo Environmental Change, and Depositional Sequences of Barremian-Aptian Shallow-Water Carbonates in Northern Oman. Sedimentology, 49, 555-581. https://doi.org/10.1046/j.1365-3091.2002.00460.x

[28] Schroeder, R. (1975) General Evolutionary Trends in Orbitolinas. Revista Espan ola de Micropaleontologia Numero Especial, 117-128.

[29] Rosenfeld, A., Hirsch, F. and Honigstein, A. (1995) Early Cretaceous Ostracodes from the Levant. Proceedings of the 12 th International Symposium on the Subclass Ostracoda and Ostracod Biostratigraph, Prague, 26-30 July 1994, 111-121.

[30] Rosenfeld, A., Hirsch, F., Honigstein, A. and Raab, M. (1998) The Palaeoenvironment of Early Cretaceous Ostracodes in Israel. In: Crasquin Soleau, S., Braccini, E. and Lethiers, F., Eds., What about Ostracoda! Bulletin des Centresde Recherche EXploration-Production Elf-Aquitaine, Memoire 20, 179-195.

[31] Matsukawa, M. and Tomishita, K. (2009) Evaluation of Studies of Stratigraphy and Sedimentary Environments of the Sanchu Cretaceoussince.

[32] Afghah, M. and Shaabanpour Haghighi, A. (2014) Aptian Biostratigraphy in South Zagros Basin, Southwest Iran.

[33] Moosavizadeh, M.A., Mahboubi, A., Moussavi-Harami, R.M.A. and Kavoosi, M.A. (2013) Early Aptian Oceanic Anoxic Event (OAE 1a) in Northeastern Arabian Plate Setting: An Example from Dariyan Formation in Zagros Fold-Trust Belt, SE Iran. 
Submit or recommend next manuscript to SCIRP and we will provide best service for you:

Accepting pre-submission inquiries through Email, Facebook, LinkedIn, Twitter, etc. A wide selection of journals (inclusive of 9 subjects, more than 200 journals)

Providing 24-hour high-quality service

User-friendly online submission system

Fair and swift peer-review system

Efficient typesetting and proofreading procedure

Display of the result of downloads and visits, as well as the number of cited articles Maximum dissemination of your research work

Submit your manuscript at: http://papersubmission.scirp.org/

Or contact ojg@scirp.org 